\title{
Thoughts on controls on evolution and dispersal of benthos in the Magellan-Scotia Sea region: a workshop proposal*
}

\author{
MICHAEL R.A. THOMSON \\ School of Earth Sciences, University of Leeds, Leeds, UK. E-mail: m.thomson@stone-house.demon.co.uk
}

\begin{abstract}
SUMMARY: The Scotia Arc and the Scotia Sea comprise a geologically young feature of the Earth's surface that evolved over the last 40 million years (Ma) or so, between the southern tip of South America and the northern tip of the Antarctic Peninsula. With the notable exception of the much younger South Sandwich Islands, the islands, banks and seamounts of the arc represent dispersed fragments of a previous continental link between southern South America (Magellan region) and the Antarctic Peninsula. The benthic marine shelf faunas of the region are the focus of the IBMANT (Investigación Biolólogica Marina en Magallanes relacionada con la Antártida) programme, and those of the surrounding oceanic deeps are the focus of ANDEEP (Antarctic Benthic Deep-Sea Biodiversity). Elucidating the potential relationships between the faunas of the region and the profound geographical, oceanographic and climatic changes undergone by the region in later Cenozoic time is hampered by significant unknowns in the geological history, the expense of further geoscientific exploration to fill these, and a general lack of communication between the biological and geological science communities. It is suggested that the time is opportune for a truly multidisciplinary workshop at which all the involved science communities have much to gain from the others.
\end{abstract}

Keywords: Antarctic, evolution, invertebrates, faunistic exchange, interdisciplinary perspectives.

RESUMEN: REFLEXIONES SOBRE LOS CONTROLES DE LA EVOLUCIÓN Y DISPERSIÓN DE ORGANISMOS BENTÓNICOS EN LA REGIÓN MAgallánica Y DE SCOTIA: unA PROPUESTA DE TRABAJO. - El Arco de Scotia y el Mar de Scotia tienen características geológicas jóvenes, que evolucionaron en los últimos 40 millones de años (Ma), a partir de los actuales Cono Sur de América del Sur y extremo septentrional de la Península Antártica. Con la notable excepción de las mucho más jóvenes Islas Sándwich del Sur, las islas, bancos y montes sumergidos del arco representan fragmentos dispersos de una conexión continental previa entre la parte austral de Sudamérica (región magallánica) y la Península Antártica. La fauna marina bentónica de plataforma de la región ha sido el objetivo del programa IBMANT (Investigación Biológica Marina en la Región Magallánica relacionada con la Antártida) y la concerniente con las profundidades oceánicas circundantes son el eje de estudio del ANDEEP (Antarctic Benthic Deep-Sea Biodiversity). La dilucidación de las relaciones potenciales entre las faunas de la región y los profundos cambios geográficos, oceanográficos y climáticos que sucedieron durante el Cenozoico tardío está dificultada por significativos desconocimientos en la historia geológica, los costos de exploraciones científicas adicionales para resolverlos, y una falta general de comunicación entre las comunidades científicas biológicas y geológicas. Se sugiere que es tiempo oportuno para un verdadero trabajo multidisciplinario en el cual las comunidades científicas involucradas tienen mucho por ganar unas de otras.

Palabras clave: Antártida, evolución, invertebrados, intercambio faunístico, perspectivas interdisciplinarias.

*Received November 1, 2004. Accepted March 10, 2005. 


\section{GEOLOGICAL AND BIOLOGICAL CHANGE IN THE MAGELLAN-SCOTIA ARC REGION}

The Scotia arc and the Scotia Sea comprise a geologically young feature of the Earth's surface that evolved over the last 40 million years (Ma) or so. Lying between the southern tip of South America and the northern tip of the Antarctic Peninsula, the region is composed geologically of a number of islands, submarine banks or seamounts and ocean deeps. With the notable exception of the much younger South Sandwich Islands, the islands, banks and seamounts represent dispersed fragments of a previous continental link between southern South America and the Antarctic Peninsula. At some time prior to $40 \mathrm{Ma}$ ago, there would have been a terrestrial link between the two continents, enabling the dispersal of land animals and plants (Reguero et al., 2002). There would also have been flanking continental shelves providing a habitat for marine benthos and related fish, the implication being that in the geological past there should have been close similarities between the benthic faunas of what now constitute the Magellan and Antarctic Peninsula regions. This scenario raises some major questions. How might the marine faunas have evolved in response to the tectonic break-up of the continental link, the dispersal of the fragments, oceanographic changes, and the major climatic deterioration across the entire region? These issues are a focus of the IBMANT (Investigación Biolólogica Marina en Magallanes relacionada con la Antártida) programme (Arntz and Ríos, 1999).

In a recent paper (Thomson, 2004), the author reviewed the literature on the geological evolution of the Scotia Sea from the point of view of an interested observer. A more detailed review addressing many of the issues raised here was published independently by Mackensen (2004). The region is infamous for its stormy seas and it is a testament to the ships' crews and scientists who have persevered over the years to map its sea bed, to chart its currents, and to unravel its geological history. Much has been written, but not all the interpretations agree and that is because there remain some critical unknowns or uncertainties, notably:

- the relative timing of events,

- the precise movement history of the continental blocks within and around the Scotia Sea, and

- the detailed palaeogeographic configuration of the region through time.

Of these, timing is arguably the most critical because, whilst many of the models put forward are ever more sophisticated, an error of one or two million years in the timing of an event (easily possible depending on the dating methods used) could turn an argument on its head. In particular, there is a substantial body of evidence suggesting that the opening of Drake Passage, the separation of the south Tasman Rise from northern Victoria Land, the onset of the Circum-Polar Current (ACC) and the development of the first Antarctic ice sheets occurred between 32.5 and 34 Ma ago (e.g. Barrett, 2001; Lawver and Gahagan, 1998). There are several chickens and eggs here and knowing the true relative order is crucial to any view on whether or not the inception of the ACC may have had a causal (or even any) effect on Antarctic glaciation (Barker and Thomas, 2004; Thomson, 2004;). Furthermore, although there is a distinct movement away (Livermore et al., 2004; Thomson, 2004) from the Barker and Burrell (1977) model, with a sliver of continental crust blocking Drake Passage until about 23.5 Ma ago, Maldonado et al. (2003) argued that, whilst Drake Passage was open to the Pacific, a deep-water passage through the east Scotia Sea was effectively blocked by an arc of continental fragments to the east and that there was a deep-water gyre within it until 20.7 Ma ago. It would seem that the ultimate effect would have been the same-no ACC until about $20 \mathrm{Ma}$ ago. Even today the ACC, the "strongest current in the world's ocean" (Barker and Thomas 2004), is constrained within the $1000 \mathrm{~km}$ wide opening of Drake Passage and further obstructed by islands and continental shallows of the Scotia arc. Given the uncertainties over the evolution of these obstacles, it is a moot point as to just when it became possible for the ACC to develop into its present vigorous state.

With the use of computer models, it is now possible to attempt some rather detailed histories of block movements and the development of oceanic basins within the Scotia Sea (Lawver and Gahagan, 2003; Eagles, 2000). However, there are still some important areas of ocean floor whose ages are poorly constrained or essentially unknown (Barker, 2001), and there are two interpretations of the movement history of South Georgia: one where it moves from an original position near the southern tip of South America, eastward along the northern margin of the Scotia Sea (Barker and Burrell, 1977; Lawver et al., 1992; Eagles, 2000), and a second where it breaks off initially with Discovery Bank (Lawver and Gahagan, 2003) and moves to the southern side of the Scotia Sea before moving subsequently north- 
east to its present position at the eastern end of the North Scotia Ridge. These two possibilities have potentially different consequences for the environmental pressures on and the evolutionary history of the faunas of the South Georgia continental shelf, and they need to be resolved.

Palaeogeography means different things to different people. In the case of the Scotia Sea, for some it can be little more than mapping the relative disposition of continental fragments within the region, but others would wish to know more about the physical structure of those fragments. For example, was there any land, how much was covered by sea and to what approximate depth, and would any significant transport of water have been possible across or between the blocks? Apart from those continental fragments where there are limited areas of land that can be visited by geologists (South Georgia, South Sandwich Islands, South Orkney Islands), we know frustratingly little about the geology of the continental blocks and even less of their continental shelves (Thomson, 2004) . Only the continental shelf of the South Orkney Islands has been sampled by drilling (Barker, Kennett et al., 1988) but then only at its margin and with poor core recovery of a partial sequence.

Whilst remote geophysical methods, such as magnetic or multi-channel seismic systems, are invaluable for providing information on a region's gross geological structure, they cannot provide hard information on whether or not any sedimentary rocks are marine or terrestrial, and offer only inferential information about age. In order to obtain precise palaeoenvironmental, stratigraphical and age information, which comes from sediment types, fossils and datable (mainly magmatic) rocks, there is no other recourse than to collect a sample. But deep-sea drilling is expensive, the Scotia Sea is stormy, and it is likely to be many years before further sampling is undertaken. Furthermore, given that geological investigations in Antarctica seem to be somewhat out of fashion at present and that the focus is more and more on short-term climate change, further progress in the collection of geological data from the Scotia Sea region may seem somewhat remote, however desirable it is.

\section{TOWARDS A SOLUTION}

Despite this somewhat gloomy prospect outlined above, there is a yet untried and novel approach that

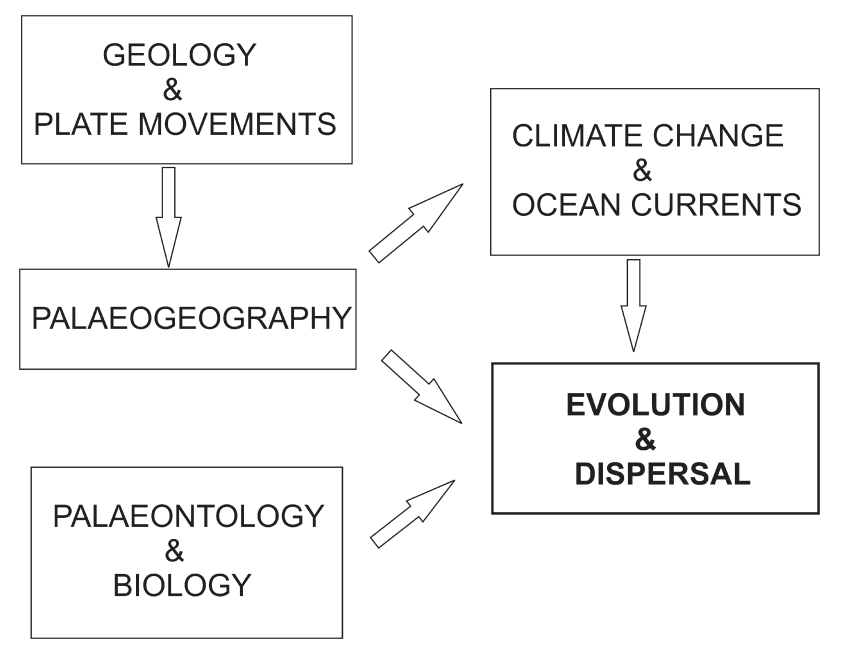

FIG. 1. - Diagram to show the interaction between key factors affecting the evolution and dispersal of benthic marine organisms in the Magellan-Scotia Sea region.

might help us to squeeze out the last drops of information from existing studies and perhaps to place some apparently unaccountable pieces of data into some meaningful context-a workshop of marine biologists, geologists and geophysicists, and palaeooceanographers. It is suggested that interaction between such disparate groups of scientists who, nonetheless have all been working on the same region, might produce some surprising advances.

Figure 1 is a simple representation of the controls on the evolution and dispersal histories of marine faunas in the Magellan-Scotia Sea region and their possible interactions. It could provide a model for structuring the workshop. Geological, landscape, and plate-movement histories control the palaeogeography which, in turn, has a profound effect on oceanic currents and climate change. Palaeogeography, palaeontology and biology, and climate change and ocean current configurations all provide data for, or act as direct controls on, the understanding of the evolution and dispersal of taxa. There are many critical questions to be posed and no doubt everyone will have their own favourites. Here are some suggestions:

- What is the best present model for the break-up history of the palaeocontinental link between South America and the Antarctic Peninsula and formation of the Scotia Arc?

- How good is the geological dating and what assumptions constrain the data and the numbers? Be honest.

- What is the best geological estimate for the onset of the ACC and is there any supporting evidence from the palaeobiological record? 
- What are the most significant controls on the distribution of benthic taxa in the region? How important was climate deterioration and ice-sheet extension?

- Are there any disparate biological distributions that might be explained by tectonic movements?

- How important is the ACC to biological distribution and evolution? It appears that it was not causal in the deterioration of the Antarctic climate, and the presence of associated eddies suggests that larvae might be able to cross it (Thatje and Fuentes, 2003; Glorioso and Leben, 2005; Thomson, 2004).

It is suggested that such a workshop, with close interaction between discipline groups that rarely have contact with each other, would lead to:

- a general clarification of the critical issues, and a better understanding of the region's geological and biological history based on a comprehensive view of available data,

- the solution of some problems or at least a new perspective on issues previously confined within a single disciplinary area, and

- identification of critical problems for further investigation.

But, most important of all, it should encourage the development of integrated cross-disciplinary studies, including multi-disciplinary cruises, in pursuit of a common goal.

\section{ACKNOWLEDGEMENTS}

Although these few words contain many of my personal prejudices, for which I must take the responsibility, I nevertheless extend sincerest thanks to many who have inspired and encouraged me to contribute to the debate and causes of the IBMANT programme. In particular I wish to thank Professor W. Arntz (Alfred-Wegener-Insitut) for including me as a geologist in his biological community, and also Professor Angelika Brandt (Universität Hamburg) for welcoming me also into the ANDEEP communi- ty and making me write the review on which this note is based.

\section{REFERENCES}

A more complete bibliography is given in Thomson (2004) and references therein; see also Mackensen (2004).

Arntz, W. and C. Ríos (eds.). - 1999. Magellan-Antarctic: ecosystems that drifted apart. Sci. Mar., 63(Suppl.1): 1-518.

Barker, P.F. - 2001. Scotia Sea regional tectonic evolution: implications for mantle flow and palaeocirculation. Earth Sci. Rev., 55: $1-39$.

Barker, P.F. and J. Burrell. - 1977. The opening of Drake Passage. Mar. Geol., 25: 15-34.

Barker, P.F. and E. Thomas. - 2004. Origin, signature and palaeoclimatic influence of the Antarctic Circumpolar Current. Earth Sci. Rev., 66: 143-162.

Barker, P.F., J.P. Kennett and the Shipboard Scientific Party. 1988. Proceedings of the ODP, Initial Reports, 113: 785 pp. Ocean Drilling Program, College Station TX.

Barrett, P.J. - 2001. Climate Change - an Antarctic perspective. NZ Sci. Rev., 58: 18-23.

Eagles, G. - 2000. Modelling plate kinematics in the Scotia Sea. $\mathrm{PhD}$ thesis, University of Leeds.

Glorioso, P.D. and R.R. Leben. - 2005. Southwest Atlantic mesoscale eddies. Sci. Mar., 69(Suppl. 2):7-15.

Lawver, L.A. and L.M. Gahagan. - 1998. Opening of Drake Passage and its impact on Cenozoic ocean circulation. In: T.J. Crowley and K.C. Burke (eds.), Tectonic boundary conditions for climate reconstructions, pp. 212-223. Oxford University Press, Oxford.

Lawver, L.A. and L.M. Gahagan. - 2003. Evolution of Cenozoic seaways in the circum-Antarctic region. Palaeogeogr. Palaeocl., 198: 11-37.

Lawver, L.A., L.M. Gahagan and M.L. Coffin. - 1992. The development of paleoseaways around Antarctica. Antarct. Res. Ser., 56: 7-30.

Livermore, R.A., G. Eagles, P. Morris and A. Maldonado. - 2004. Shackleton Fracture Zone: no barrier to early circumpolar ocean circulation. Geology, 32: 797-800.

Mackensen, A. - 2004. Changing Southern Ocean palaeocirculation and effects on global climate. Antarct. Sci., 16: 369-386.

Maldonado, A., A. Barnolas, F. Bohoyo, J. Galindo-Zaldívar, J. Hernández-Molina, F. Lobo, J. Rodríguez-Fernández, L. Somoza and J.T. Vázquez. - 2003. Contourite deposits in the central Scotia Sea: the importance of the Antarctic Circumpolar Current and the Weddell Gyre flows. Palaeogeogr. Palaeocl., 198: $187-221$.

Reguero, M.A., S.A. Marenssi and S.N. Santillana. - 2002. Antarctic Peninsula and South America (Patagonia) Paleogene terrestrial faunas and environments: biogeographic relationships. Palaeogeogr. Palaeocl., 179: 189-210.

Thatje, S. and V. Fuentes. - 2003. First record of anomuran and brachyuran larvae (Crustacea: Decapoda) from Antarctic waters. Polar Biol. 26: 279-282.

Thomson, M.R.A. - 2004. Geological and palaeoenvironmental history of the Scotia Sea region as a basis for biological interpretation. Deep-Sea Res. II, 51: 1467-1487. 